\title{
The Influence of pH Spitting on the Internal Resistance in Microbial Fuel Cells
}

\author{
Zhang Songhe*. \\ Ministry of Education Key Laboratory of Integrated \\ Regulation and Resource Development on Shallow Lakes \\ College of Environment, Hohai University \\ Nanjin, China. \\ Shzhang@hhu.edu.cn
}

\author{
Hui Yuxin \\ Ministry of Education Key Laboratory of Integrated \\ Regulation and Resource Development on Shallow Lakes \\ College of Environment, Hohai University \\ Nanjin, China. \\ hyx0824@126.com
}

\begin{abstract}
Membrane separator in microbial fuel cell (MFCs) is one of the main factors that could significantly affect the performance of MFC. Proton exchange membranes (PEMs) are typically used in two-chamber microbial fuel cells to separate the anode and cathode chambers while to allow the transfer of protons from anode to the cathode. However, protons will accumulate in the anode chamber, and therefore and the $\mathrm{pH}$ balance will be broken if the MFC works for a long time. In this study, effects of two types of separator membranes (Proton Exchange Membrane; $0.45 \mu \mathrm{m}$ Synthetic Fabric Membrane) on the pH spitting and MFC performance were investigated. Membrane internal resistance, membrane biofouling and oxygen diffusion were also analyzed. The fouling layer attached on membranes consisted of microorganisms was demonstrated from imaging analysis coupled with SEM. We found that $\mathrm{pH}$ splitting might influence MFC internal resistance more than biofouling. This was attributed to the proton transfer process, which was influenced by cathode pH value.
\end{abstract}

Keywords-component; internal resistance; pH spitting; biofouling; membrane; microbial fuel cells (MFC).

\section{INTRODUCTION}

Microbial fuel cells (MFCs) have been of concern worldwide due to their dual functionality for organic waste degradation as well as energy production ${ }^{[1]}$. MFCs are devices that convert a portion of the chemical energy within organic matter to usable biogenic electrical energy with the help of bacteria as biocatalysts ${ }^{[2-4]}$.

Separator is one of the most important components in MFCs. Nafion has been widely used as separator for $\mathrm{MFCs}^{[5]}$, and has large advantage of being very selective for stability. However, continuous operation of MFC with Nafion causes alkalinization at the cathode as a result of consumption of protons, and acidification is observed on the anode side due to the continuous accumulation of protons, which result from slow and incomplete proton

\author{
Han Bing \\ Ministry of Education Key Laboratory of Integrated \\ Regulation and Resource Development on Shallow Lakes \\ College of Environment, Hohai University \\ Nanjin, China. \\ 304732166@qq.com
}

diffusion and migration through the membrane ${ }^{[6]}$. The driving force of a typical MFC using glucose as fuel can be articulated at anode and cathode, respectively, as follows ${ }^{[7]}$.

$$
\begin{aligned}
& \mathrm{C}_{6} \mathrm{H}_{12} \mathrm{O}_{6}+6 \mathrm{H}_{2} \mathrm{O} \rightarrow 6 \mathrm{CO}_{2}+24 \mathrm{H}^{+}+24 \mathrm{e}^{-} \\
& 6 \mathrm{O}_{2}+24 \mathrm{H}^{+}+24 \mathrm{e}^{-} \rightarrow 12 \mathrm{H}_{2} \mathrm{O}
\end{aligned}
$$

These phenomena lead to a membrane $\mathrm{pH}$ spitting which puts an electrochemical/thermodynamic limitation on MFC performance ${ }^{[8]}$.

In anolytes of MFC acidic conditions inhibits the oxidation activity of bacteria and reduces proton production ${ }^{[9-12]}$. According to the Nernst equation, the increased $\mathrm{pH}$ in the cathode compartment can significantly decrease current generation, while a balance of $\mathrm{pH}$ value between two chambers would be benefit for the potential of the oxygen reduction reaction. The oxygen reduction should increase with a decrease of the operational $\mathrm{pH}$, and the current output from MFCs would be increased ${ }^{[6 ; 9-11]}$.

However, up to now, few studies have been systemically conducted on the relevance of the membranes pores to $\mathrm{pH}$ spitting. Therefore, due to the important role of the $\mathrm{pH}$ gradient in the $\mathrm{MFC}^{[13]}$, the focus of this study is to examine the effect of membrane with $0.45 \mu \mathrm{m}$ pore on $\mathrm{pH}$ gradient, internal resistance, power generation, chemical oxygen demand (COD) removal and columbic efficiency for MFC. Biofouling of the membranes is also investigated.

\section{MATERIALS AND METHODS}

\section{A. MFC construction and operation}

A dual-chamber MFC was configured with the anode and cathode each in a $288 \mathrm{~mL}$ chamber. Two ports for sampling and introducing electrodes in the top of anodechamber, and sealed with thick rubber stoppers during operation. The anode was a carbon fiber felt $\left(4 \times 2 \mathrm{~cm}^{2}\right.$, 
Q-CARBON MATERIAL CO., China), the cathode was carbon paper with $\mathrm{Pt}$ on it $\left(4 \times 2 \mathrm{~cm}^{2}, 1 \mathrm{mg} / \mathrm{cm}^{2}\right.$, River's electric co., LTD., Shanghai, China). Proton exchange membrane (PEM, N117CS, DuPont) and $0.45 \mu \mathrm{m}$ synthetic fabric membrane $(0.45 \mu \mathrm{m}-\mathrm{SFM}$, Haining guodian taoyuan medical chemical factory) were used to separate the anode and cathode chamber. The PEM is consisted of a hydrophobic fluorocarbon backbone $\left(-\mathrm{CF}_{2}-\right.$ $\left.\mathrm{CF}_{2-}\right)$ and hydrophilic sulfonate groups $\left(\mathrm{SO}_{3}^{2-}\right) .0 .45 \mu \mathrm{m}-$ SFM $(\Phi 3 \mathrm{~cm})$ is made from cellulose acetate and cellulose nitrate.

All exposed metal surfaces were sealed with a nonconductive epoxy resin. The schematic diagram of experimental set-up of the MFC is in Fig .1.

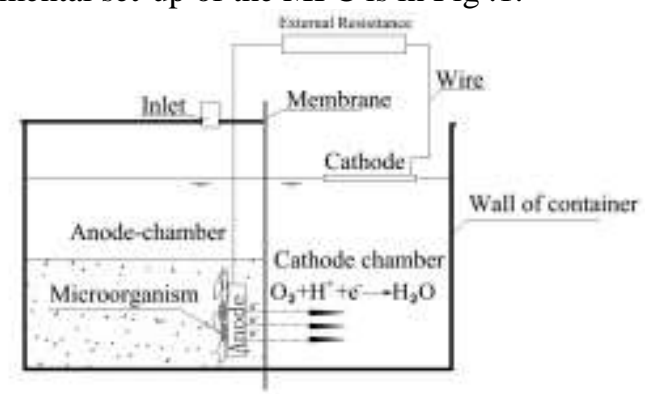

Figure 1. Dual chamber MFC

The anode chamber of the reactor was filled with 100 $\mathrm{ml}$ excess sludge from wastewater plant cultured as microbial bioanodes and glucose $(\mathrm{COD}=1000 \mathrm{mg} / \mathrm{l})$ as fuel. Both cathode and anode compartments of all MFCs were filled with $50 \mathrm{mM}$ phosphate buffer solution $(0.31$ $\mathrm{g} / \mathrm{L} \mathrm{NH} \mathrm{NH}_{4}, 0.13 \mathrm{~g} / \mathrm{L} \mathrm{KCl}, 3.32 \mathrm{~g} / \mathrm{L} \mathrm{Na}_{2} \mathrm{HPO}_{4} \cdot 12 \mathrm{H}_{2} \mathrm{O}$, $\left.10.32 \mathrm{~g} / \mathrm{L} \mathrm{NaH} \mathrm{PO}_{4} \cdot 2 \mathrm{H}_{2} \mathrm{O}, \mathrm{pH}=7.0\right)$, and add $1 \mathrm{ml}$ per liter trace elements electrode buffer $\left(\mathrm{CoCl}_{2} \cdot 6 \mathrm{H}_{2} \mathrm{O}, 0.10 \mathrm{~g} / \mathrm{L}\right.$; $\mathrm{CuSO}_{4} \cdot 5 \mathrm{H}_{2} \mathrm{O}, \quad 0.01 \mathrm{~g} / \mathrm{L} ; \mathrm{MnSO}_{4} \cdot \mathrm{H}_{2} \mathrm{O}, 0.50 \mathrm{~g} / \mathrm{L} ; \mathrm{NaCl}$, $1.00 \mathrm{~g} / \mathrm{L} ; \mathrm{CaCl}_{2} \cdot 2 \mathrm{H}_{2} \mathrm{O}, 0.10 \mathrm{~g} / \mathrm{L} ; \mathrm{MgSO}_{4} \cdot 7 \mathrm{H}_{2} \mathrm{O}, 3.00 \mathrm{~g} / \mathrm{L}$; $\left.\mathrm{ZnCl}_{2}, 0.13 \mathrm{~g} / \mathrm{L} ; \mathrm{FeSO}_{4}, 0.10 \mathrm{~g} / \mathrm{L}\right)^{[14]}$. The MFCs were operated at ambient temperature conditions in the laboratory $\left(20 \pm 3^{\circ} \mathrm{C}\right)$ with a $1000 \Omega$ resistor except as noted. Nitrogen gas was flushed for $5 \mathrm{~min}$ into the anodic chamber to remove dissolved oxygen in order to maintain anoxic conditions.

The $\mathrm{pH}$ value of cathode solution was measured by $\mathrm{pH}$ meter (Puxico, P4-036). Polarization curves were obtained by using varying external resistance from 2000 to $100 \Omega$, cell voltage data were recorded ever $10 \mathrm{~min}^{[15]}$ for each resistance with a digital multmeter (VC88E, Shenzhen Victor Hi-tech CO,. LTD. China). The polarization curves of the MFC with the fouled membrane were plotted. After one more month, all the performance parameters of MFC were measured at three more times when the current was stable.

Dissolved oxygen analyzer (HACH sensION6) was placed in the anode chamber. And the water was flushed with nitrogen gas to remove DO. The cathode chamber was continuously aerated to maintain the saturated DO concentration. The mass transfer coefficient of oxygen in the membrane, $k_{\mathrm{o}}$, was determined by monitoring the DO concentration over time and using the equation by Kim and co-workers ${ }^{[16]}$

$k_{o}=-\frac{V}{A t} \ln \left[\frac{C_{0}-C_{1}}{C_{0}}\right]$
Where $\mathrm{V}$ is the liquid volume in the anode chamber, $\mathrm{A}$ is the membrane cross-sectional area, $\mathrm{c}_{0}$ is the saturated oxygen concentration in the cathode chamber and $c_{1}$ is the DO in the anode chamber at time $t$. The diffusion coefficient $D_{0}$ was calculated as $D o=k_{0} * L$, where $L$ is the membrane thickness.

The coulombic efficiency (CE) was calculated as

$$
\mathrm{CE}(\%)=\frac{C_{P}}{C_{T}} \times 100 \%
$$

where $C_{P}$ is the total coulombics calculated by integrating the current over time and $\mathrm{C}_{\mathrm{T}}$ is the theoretical amount of coulombics based on the COD removed by assuming $4 \mathrm{~mol}$ of electrons per mol of COD.

\section{B. Scanning electron microscope (SEM)}

For SEM analysis, part of the fouled membrane was cut into pieces and immersed in $2.5 \%$ glutaraldehyde for 1h. They were then subjected to dehydration using a serial diluted ethanol $(30 \%, 50 \%, 70 \%, 80 \%$ and $90 \%, 15$ min for each concentration; $100 \%, 15 \mathrm{~min}$ twice) and then dried completely at ambient temperature. The microscopic structure and elemental components of the membrane surface was analyzed using JSM-200CX SEM (JEOL Co., Japan).

\section{Fluorescence spectroscopy}

The excitation-emission matrices (EEMs) were obtained using a Hitachi F7000 spectra fluorimeter. The samples were taken from cathode chamber and anode chamber. Each sample was centrifuged $5 \mathrm{~min}$ in $5000 \mathrm{xr}$ and analyzed in a $10 \mathrm{~mm}$ quartz cuvette maintained at a constant room temperature of $20{ }^{\circ} \mathrm{C}$. For each sample, a simultaneous scan was performed of excitation and emission wavelengths from 200 600 and from 200 600 $\mathrm{nm}$, respectively, with intervals of $10 \mathrm{~nm}$. A $10 \mathrm{~nm}$ slit, both for excitation and emission, was used, with a scanning rate of $1200 \mathrm{~nm} / \mathrm{min}$.

\section{RESULT}

\section{A. The characteristics of the MFCs}

The polarization curve of the MFCs under steady conditions were plotted (Fig .2) during the changing of $\mathrm{pH}$ value. The maximum power densities, internal resistance, COD removal and CE of $0.45 \mu \mathrm{m}-\mathrm{SFM}$ and PEM were analyzed (TABLE I). The maximum power densities of two MFCs were similarly at initial stage. However, after a long period running, the maximum power density of PEM-MFC increased by $24.6 \%$, and that of $0.45 \mu \mathrm{m}-\mathrm{SFM}-\mathrm{MFC}$ increase by $49.5 \%$. These difference may be ascribed to the reason that a few days were required to reach a new steady-state current after change the buffer solutions[17].

The initial internal resistance of $0.45 \mu \mathrm{m}-\mathrm{SFM}-\mathrm{MFC}$ was lower than that of PEM-MFC, suggesting that the holes in $0.45 \mu \mathrm{m}-\mathrm{SFM}-\mathrm{MFC}$ may contribute to the decrease of internal resistance. However, after 16 days running internal resistances in MFCs with $0.45 \mu \mathrm{m}-\mathrm{SFM}$ did not change obviously while that with PEM decreased significantly. 

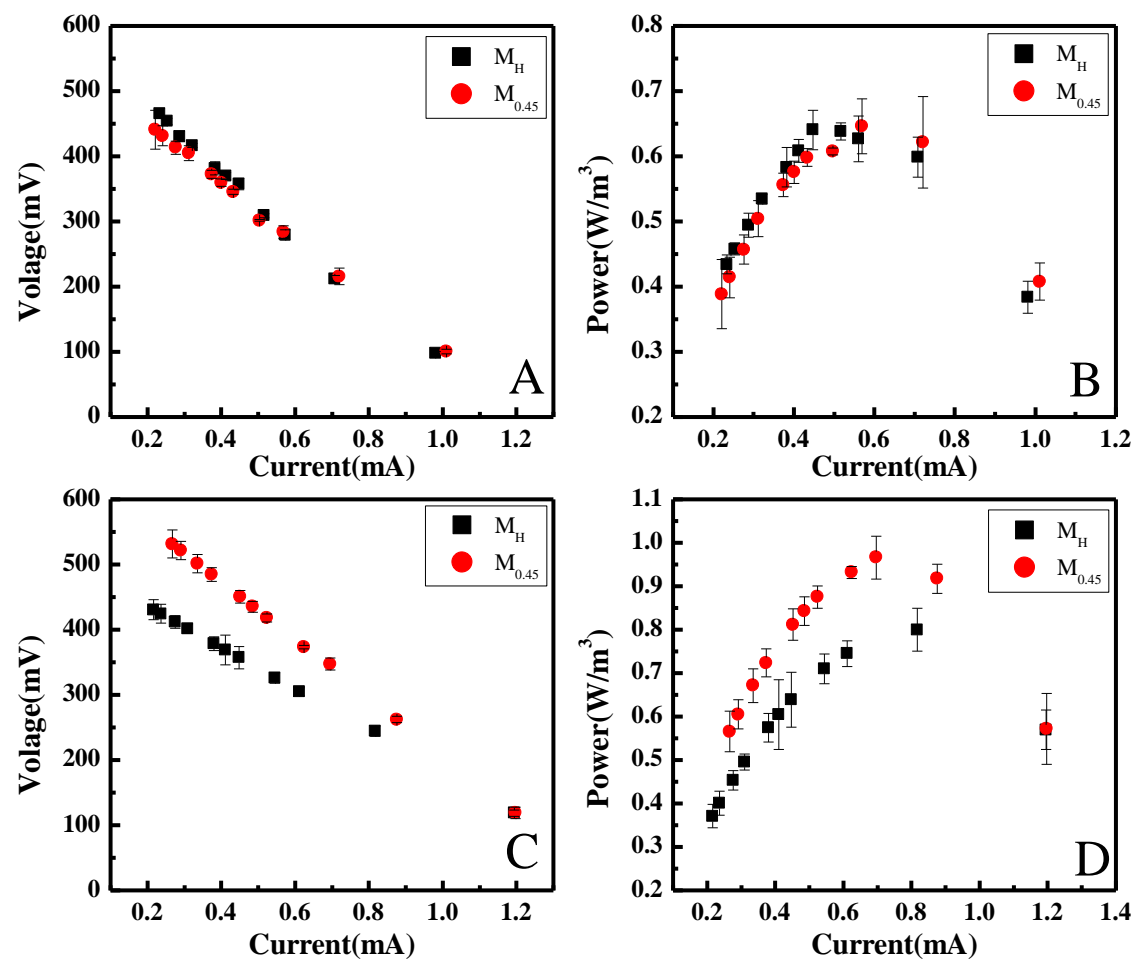

Figure 2. Polarization curves and voltage-current curves of two kinds of double-chamber MFC. (A) Voltage-current curves (Cathode pH=7); (B) Polarization curves (Cathode $\mathrm{pH}=7$ ); (C) Voltage-current (The $\mathrm{pH}$ of PEM-MFC cathode chamber>9); (D) Polarization curves in the end (The pH of PEM-MFC cathode chamber>9)

TABLE I . COMPARISON OF THE PERFORMANCE OF MFCS WITH PEM AND

$0.45 \mu \mathrm{m}-S F M$ IN TERMS OF MAXIMAL POWER DENSITY, INTERNAL RESISTANCE, COD REMOVAL AND COULOMBIC EFFICIENCY (MEAN VALUE \pm STANDARD DEVIATION).

\begin{tabular}{|c|c|c|c|c|c|c|}
\hline \multirow{2}{*}{ Membrane } & \multicolumn{2}{|c|}{$\begin{array}{l}\text { Maximal power } \\
\text { density }\left(\mathbf{m W} \mathbf{m}^{-3}\right)\end{array}$} & \multicolumn{2}{|c|}{$\begin{array}{c}\text { Internal resistance } \\
(\Omega)\end{array}$} & \multirow{2}{*}{$\begin{array}{c}\text { COD } \\
\text { removal } \\
(\%)\end{array}$} & \multirow{2}{*}{$\begin{array}{c}\text { Coulombic } \\
\text { efficiency }(\%)\end{array}$} \\
\hline & $\begin{array}{c}\text { Cathode } \\
p H=7\end{array}$ & $\begin{array}{l}\text { Cathode } \\
\text { pH>9* }\end{array}$ & $\begin{array}{c}\text { Cathode } \\
\text { pH=7 }\end{array}$ & $\begin{array}{l}\text { Cathode } \\
\text { pH>9* }\end{array}$ & & \\
\hline PEM & $639 \pm 13$ & $796 \pm 49$ & $498.4 \pm 26.6$ & $318.8 \pm 25$ & $89 \pm 6.7$ & $36.4 \pm 6.3$ \\
\hline $0.45 \mu \mathrm{m}-\mathrm{SFM}$ & $647 \pm 42$ & $967 \pm 49$ & $448.5 \pm 12.8$ & $443.3 \pm 69$ & $97 \pm 3.7$ & $21.7 \pm 2.1$ \\
\hline
\end{tabular}

*Cathode $\mathrm{pH}$ : The $\mathrm{pH}$ of PEM-MFC cathode chamber.

B. $p H$

TABLE II. OXYGEN MASS

TRANSFER $\left(\mathrm{K}_{0}\right)$,DIFFUSION

COEFFICIENTS $\left(\mathrm{D}_{0}\right)$ IN MFC WITH

DIFFERENT SEPARATORS

\begin{tabular}{|c|c|c|c|}
\hline Membranes & $\begin{array}{c}\mathrm{K}_{0} \\
\left(10^{-4} \mathrm{~cm} / \mathrm{s}\right)\end{array}$ & $\begin{array}{c}\mathrm{D}_{0} \\
\left(10^{-6} \mathrm{~cm}^{2} / \mathrm{s}\right)\end{array}$ & $\begin{array}{c}\text { Thickness } \\
(\mathrm{mm})\end{array}$ \\
\hline $\mathbf{M}_{\mathbf{H}}$ & 2.1 & 3.99 & 0.19 \\
\hline $\mathbf{M}_{\mathbf{0 . 4 5}}$ & 9.7 & 12.61 & 0.13 \\
\hline
\end{tabular}

In order to investigate the influence of pore size of membranes on the protons transfer and the MFC performance, the oxygen diffusion coefficients (Do) through the membranes were measured. The oxygen diffusion coefficients and mass transfer $\left(\mathrm{K}_{0}\right)$ increased in the medium of $0.45 \mu \mathrm{m}-\mathrm{SFM}-\mathrm{MFC}$ as compared to that of PEM-MFC (TABLE II). Kim ${ }^{[16]}$ demonstrated that the oxygen transfer coefficient in ultrafiltration membranes increased with the membrane pore size which may cause CE decrease. So the CE of $0.45 \mu \mathrm{m}-\mathrm{SFM}-\mathrm{MFC}$ was lower than that of PEM-MFC.

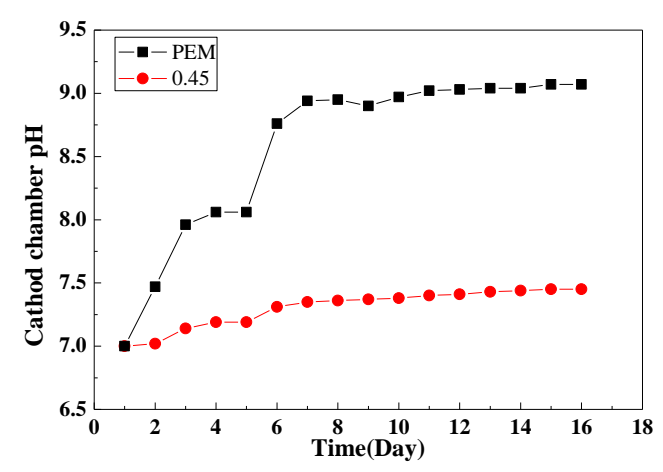

Figure 3. $\mathrm{pH}$ in the cathode chamber as a function of operating time. 


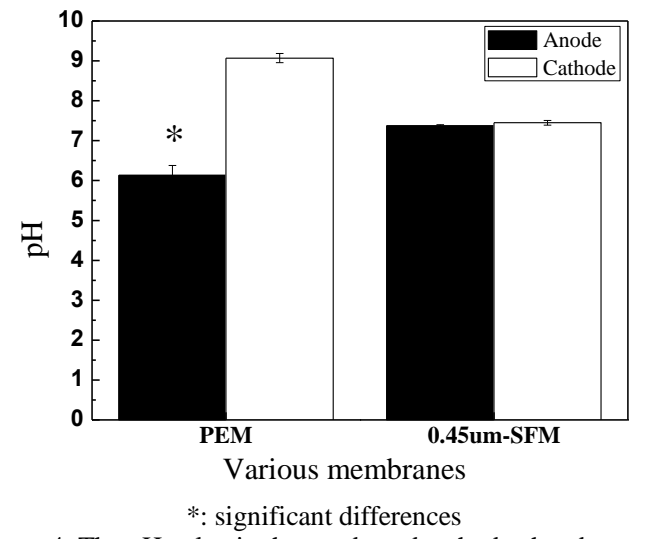

Figure 4. The $\mathrm{pH}$ value in the anode and cathode chambers after 16day stable operation of MFC.

In situ $\mathrm{pH}$ variations at the cathode chamber were measured to determine the real $\mathrm{OH}^{-}$cathode profiles during MFC operation. Oxygen reduction reaction (ORR) occurred in the cathode regions causing the alkaline under closed-circuit way (Fig .3), and variations in $\mathrm{pH}$ change large related to the aperture of membranes (Fig .4). The $\mathrm{pH}$ of the cathode started to increase when current generation was initiated, and it increases over time. Phosphate buffer is typically used to minimize $\mathrm{pH}$ variation in MFCs, and the $0.45 \mu \mathrm{m}-\mathrm{SFM}$ permit $\mathrm{H}^{+}$and $\mathrm{OH}^{-}$transfer easily between cathode and anode chamber. Therefore, the $\mathrm{pH}$ spitting of $0.45 \mu \mathrm{m}-\mathrm{SFM}-\mathrm{MFC}$ and PEM-MFC was 0.08 and 2.94 respectively.

Low $\mathrm{pH}$ value at cathode can inhibit the proton transfer process, and therefore, result in the increase of internal resistance at the cathode ${ }^{[18]}$. Therefore, internal resistance of the PEM-MFC is much lower than that of $0.45 \mu \mathrm{m}$-SFM when the $\mathrm{pH}$ value of the PEM-MFC cathode chamber increased to 9 .

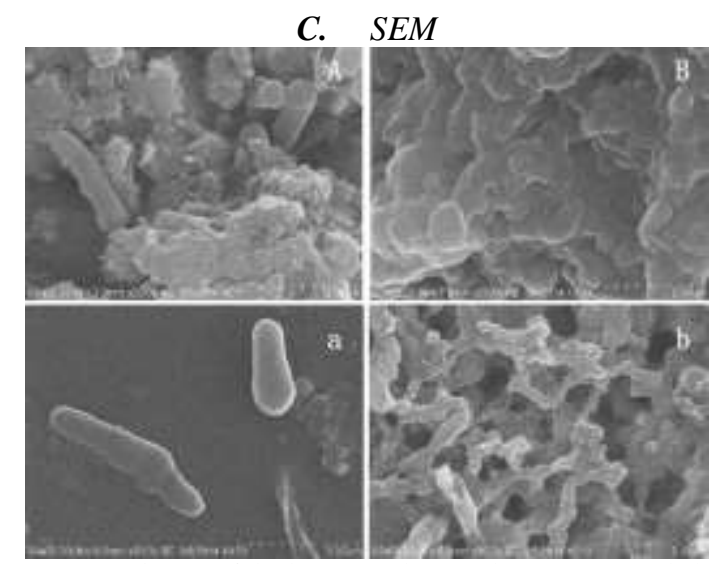

Figure 5. SEM image of the layers on the membranes. (A) Fouled PEM

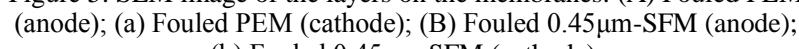
(b) Fouled $0.45 \mu \mathrm{m}-\mathrm{SFM}$ (cathode).

The morphology of the fouling layer of the membrane used in the MFC was imaged using SEM. The SEM images (Fig .3 A, B) show that a lot of microbial extracellular polymeric formed on the anode surface of PEM and $0.45 \mu \mathrm{m}$-SFM. Oppositely, only few microorganisms can be observed on the cathode surface of PEM. But, it should be noted that $0.45 \mu \mathrm{m}$-SFM had a large aperture (Fig .3) and contributed to the proton transferring from anode chamber to the cathode one. It also proved that, the $0.45 \mu \mathrm{m}$ pore could overcome the problem of blockage and reduced the membrane resistance. However, the internal resistance of $0.45 \mu \mathrm{m}$ SFM-MFC is higher than the one of PEM-MFC, which result from the $\mathrm{pH}$ spitting.

In conclusion, the $\mathrm{pH}$ spitting might influence MFC internal resistance more than biofouling.

\section{Analysis of spectroscopic data}
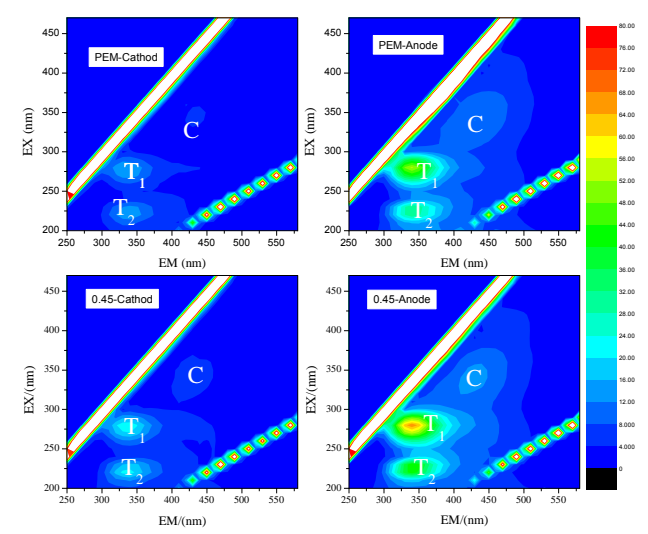

Figure 6. Example EEM illustrating positions of peaks $\mathrm{T}_{1}, \mathrm{~T}_{2}$ and $\mathrm{C}$ recognized in present investigation. Scale of fluorescence intensity is expressed in arbitrary units.

Based on analysis of the EEM illustrating, the $T_{1}$ fluorophore in the excitations $(\lambda \mathrm{ex}=275-296)$ and emission $(\lambda \mathrm{em}=340-380)$ ranges were determined; while peak $\mathrm{T}_{2}$ exhibited fluorescence between $216-237 \mathrm{~nm}$ and 340-380 $\mathrm{nm}$ for excitation and emission wavelengths. Peak C was found between excitation wavelengths 300 $370 \mathrm{~nm}$ and emission wavelengths $400-500 \mathrm{~nm}$ (Fig .5). Peaks $T_{1}, T_{2}$ and $C$ appeared in all samples. Peaks that represent biological substances were the tryptophan $\left(\mathrm{T}_{1}\right.$, $\left.\lambda \mathrm{ex} / \mathrm{em}=275-296 / 340-380 ; \mathrm{T}_{2}, \lambda \mathrm{ex} / \mathrm{em}=216-237 / 340-380\right)$ and humic $(\mathrm{C}, \lambda \mathrm{ex} / \mathrm{em}=300-370 / 400-500)^{[19]}$. The concentrations of organic matter in the $0.45 \mu \mathrm{m}-\mathrm{SFM}$ MFC cathode were higher than that in the PEM-MFC cathode, which proved the $0.45 \mu \mathrm{m}$ pore membrane could improve the proton transfer.

Combination with the electrochemical property analysis (Fig .2), the power density and the tryptophan concentration increased in $0.45 \mu \mathrm{m}-\mathrm{SFM}-\mathrm{MFC}$ cathode after MFC operation for a long period of time. Sono (1986) reported that tryptophan can react with $\mathrm{O}_{2}$ in producing formylkynurenine in cathode chamber ${ }^{[20]}$. Also, it is reported ${ }^{[21]}$ that an intervening tryptophan residue can facilitate electron transfer between distant metal redox centers in a mutant Pseudomonas aeruginosa. Therefore, tryptophan would improve the electron transfer rate so as to promote the output power of MFC.

\section{CONCLUSION}

It is concluded that the smaller the difference in $\mathrm{pH}$ value between cathode and anode, the bigger the resistance of the proton transfer was, although the fouling on the PEM was more thicker than that on SFM. The $\mathrm{pH}$ spitting has a great impact on the internal resistances of MFCs. Also, we can predict that the tryptophan in cathode affected the output power density to some extent. 
However, more work will be done in future to verify the role of tryptophan.

\section{ACKNOWLEDGMENT}

We thank for the support from National Natural Science Foundation of China (NO. 51379063) and Jiangsu Provincial Natural Science Foundation (NO. BK2012413).

\section{REFERENCES}

[1] Li W-W, Yu H-Q, He Z. Towards sustainable wastewater treatment by using microbial fuel cells-centered technologies[J]. Energy \& Environmental Science, 2014, 7(3): 911-924.

[2] Habermann W, Pommer E. Biological fuel cells with sulphide storage capacity[J]. Applied microbiology and biotechnology, 1991, 35(1): 128-133.

[3] Timmers R A, Strik D P, Hamelers H V, et al. Electricity generation by a novel design tubular plant microbial fuel cell[J]. Biomass and Bioenergy, 2013, 51: 60-67.

[4] Hyeonjin J, Yunghun Y, Kumaran R, et al. Production of algal biomass (Chlorella vulgaris) using sediment microbial fuel cells[J]. Bioresource Technology, 2012, 109: 308-311.

[5] Ghasemi M, Wan Daud W R, Ismail M, et al. Effect of pre-treatment and biofouling of proton exchange membrane on microbial fuel cell performance[J]. international journal of hydrogen energy, 2013, 38(13): 5480-5484.

[6] Oliveira V B, Simões M, Melo L F, et al. Overview on the developments of microbial fuel cells[J]. Biochemical Engineering Journal, 2013, 73(0): 53-64.

[7] Rabaey K, Lissens G, Verstraete W. Microbial fuel cells: performances and perspectives[J]. Biofuels for fuel cells: renewable energy from biomass fermentation, 2005: 377-399.

[8] Leong J X, Daud W R W, Ghasemi M, et al. Ion exchange membranes as separators in microbial fuel cells for bioenergy conversion: A comprehensive review[J]. Renewable \& Sustainable Energy Reviews, 2013, 28: 575-587.

[9] Cord-Ruwisch R, Law Y, Cheng K Y. Ammonium as a sustainable proton shuttle in bioelectrochemical systems[J]. Bioresource Technology, 2011, 102(20): 9691-9696.

[10] Cheng S, Dempsey B A, Logan B E. Electricity generation from synthetic acid-mine drainage (AMD) water using fuel cell
technologies[J]. Environmental Science \& Technology, 2007, 41(23): 8149-8153.

[11] Ren Z, Ward T E, Regan J M. Electricity production from cellulose in a microbial fuel cell using a defined binary culture[J]. Environmental Science \& Technology, 2007, 41(13): 4781-4786.

[12] Jadhav G S, Ghangrekar M M. Performance of microbial fuel cell subjected to variation in $\mathrm{pH}$, temperature, external load and substrate concentration[J]. Bioresource Technology, 2009, 100(2): 717-723.

[13] Tang X, Guo K, Li H, et al. Microfiltration membrane performance in two-chamber microbial fuel cells[J]. Biochemical Engineering Journal, 2010, 52(2): 194-198.

[14] Lovley D R, Phillips E J. Novel mode of microbial energy metabolism: organic carbon oxidation coupled to dissimilatory reduction of iron or manganese[J]. Applied and environmental microbiology, 1988, 54(6): 1472-1480.

[15] Kim K-Y, Yang E, Lee M-Y, et al. Polydopamine Coating Effects on Ultrafiltration Membrane to Enhance Power Density and Mitigate Biofouling of Ultrafiltration Microbial Fuel Cells (UFMFCs)[J]. Water Research, 2014.

[16] Kim J R, Cheng S, Oh S-E, et al. Power generation using different cation, anion, and ultrafiltration membranes in microbial fuel cells[J]. Environmental Science \& Technology, 2007, 41(3): 10041009.

[17] Chang I S, Jang J K, Gil G C, et al. Continuous determination of biochemical oxygen demand using microbial fuel cell type biosensor[J]. Biosensors and Bioelectronics, 2004, 19(6): 607-613.

[18] Sleutels T H, Ter Heijne A, Buisman C J, et al. Bioelectrochemical systems: an outlook for practical applications[J]. ChemSusChem, 2012, 5(6): 1012-1019.

[19] Hudson N, Baker A, Ward D, et al. Can fluorescence spectrometry be used as a surrogate for the Biochemical Oxygen Demand (BOD) test in water quality assessment? An example from South West England[J]. Science of the total environment, 2008, 391(1): 149-158.

[20] Sono M. Spectroscopic and equilibrium properties of the indoleamine 2, 3-dioxygenase-tryptophan-oxygen ternary complex and of analogous enzyme derivatives. Tryptophan binding to ferrous enzyme adducts with dioxygen, nitric oxide, and carbon monoxide[J]. Biochemistry, 1986, 25(20): 6089-6097.

[21] Shih C, Museth A K, Abrahamsson M, et al. Tryptophanaccelerated electron flow through proteins[J]. Science, 2008, 320(5884): 1760-1762. 